\title{
Выпушчаны на волю голас франтавіка i важака камсамольцаў Беларусі
}

\author{
(Лев Смиловицкий. Из опыта пережитого. Воспоминания. \\ Иерусалим, 2016 г. 191 с., 93 илл.)
}

Я не прыхільнік друкаваных мемуараў савецкіх людзей, асабліва начальнікаў. Што ні аўтар, то герой. I ўсё так нудна. Таму без асаблівага жадання ўзяўся за чытанне ўспамінаў Льва Мацвеевіча (Лейбы Мотелевіча) Смілавіцкага (1925-1997 гг.), які ваяваў, а потым займаў высокія пасады ў кіраўніцтве савецкай Беларусі. Аднак калі адкрыў кнігу, так і не змог адаравацца, пакуль не дачытаў да апошняй старонкі.

Найперш атрымліваў задавальненне ад лёгкасці стылю. У аўтара быў яўна літаратурны талент. Нездарма ж ён пісаў выступленні для Пятра Машэрава, калі працаваў пад яго кіраўніцтвам ў ЦК камсамола Беларусі на пасадзе намесніка загадчыка аддзела агітацыі і прапаганды.

Аўтар цікава сведчыць пра малавядомыя моманты 3 гісторыі савецкага жыцця перадваеннай Рэчыцы і савецкага тылу ў час вайны. Свой франтавы шлях ад Смаленска да сустрэчы 3 амерыканскімі салдатамі на Одары ён напаўняе не пераможнымі рэляцыямі, а апісаннем жорсткага трагізма франтавых будняў, у якіх знаходзіўся савецкі салдат. Балюча адгукнуліся ў яго ўспамінах праблемы пасляваенный рэпатрыяцыі і савецкіх турмаў, з якімі сутыкнуўся пасля вайны. I што важна, Леў Мацвеевіч дае ўнікальныя сведчанні пра стыль камсамольскага 
кіраўніцтва ў БССР 1950-х гадоў. Яму як прадстаўніку партыйнай наменклатуры, было што расказаць і пра ўдзел у калектывізацыі Заходняй Беларусі, і пра мабілізацыю камуністаў на вырашэнне аграрных праблем пры Нікіце Хрушчове.

Расказ прываблівае незвычайнай шчырасцю. Пра сваё мінулае жыццё Леў Смілавіцкі доўга хаваў, насіў з сабой. I нарэшце ў канцы 1980-х узнікла магчымасць выпусціць думкі на волю. I Леў Мацвеевіч загаварыў, пачаў выкладаць перад сынам Леанідам Смілавіцкім былыя думкі ўслых. Успаміны запісаны ў форме інтерв'ю. Зразумела, што бацька сказаў сыну толькі пра тое, што лічыў найбольш важным, што яго асабліва хвалявала, i адказаць толькі на тыя пытанні, якія змог задаць 33-х гадовы сын. Гэта - не аўтабіяграфія. Так, ва ўспамінах слаба прадстаўлены нацыянальныя моманты, праявы антысемітызму. Перашкаджаў, відаць, унутраны цэнзар, пра які ўзгадвае ў прадмове і Леанід Львовіч. Але, відавочна ж, уплавала і тая акалічнасць, што Леў Смілавіцкі, як і многія беларускія інтэлігенты, быў яўрэям ушчэнт асіміліраваным. Ды і асцерагаўся такой далікатнай тэмы як нацыянальныя адносіны. А на фронце антысемітызм не быў такім відавочным, каб урэзаўся ў памяць маладога салдата. Права аддаць жыццё за радзіму і Сталіна нікім не аспрэчвалася.

Адной $з$ адметнасцяў успамінаў Льва Смілавіцкага насычанасць іх апісаннем уласных псіхалагісных перажыванняў. Так, пры гаворцы пра вайну, ён раскрывае псіхалагічны стан простага салдата ў розных франтавых сітуацыях. Пра гераічнае жыццё на фронце ён вядзе размову не ад сябе асабіста, а ад імя франтавікоў-аднагодкаў, каму не споўнілася і 20-ці. Многае тлумачыць прызнанне аўтара, што яго сябры ў Рэчыцы хацелі вайны. На гараванне маці падлетак адказваў, што вайна гэта добра, бо мы можам вызначыцца, пойдзем на фронт, за некалькі дзён разаб'ем фашыстаў і вызвалім усіх людзей (с.18). Ужо ў Рэчыцы, яшчэ школьнікам, герой успамінаў запісаўся ў народнае 
апалчэнне. Рамантычныя юнацкія перакананні сутыкнуліся 3 жорсткай рэчаіснасцю: самая моцная армія і адступае. Яшчэ да фронта дабраахвотнікі захацелі да бацькоусскай хаты (с.36).

Выхаваны ў духу камуністычных каштоўнасцяў і савецкага патрыятызму, 17-гадовы юнак усё ж рвецца на фронт, запісваецца дабраахвотнікам, ваюе не шкадуючы жыцця, цудам выжывае. На фронце яго, як і цалкам савецкую моладзь, ахоплівае патрыятычны ўздым на ўзроўні самаахвярнасці. “Іначай бы не перамаглі”, - робіць заключэнне былы франтавік. "Гэта ўжо калі мне мінула гадоў 40, я зразумеў, як доўга хадзіў па лязу брытвы і якой небяспецы падвяргаў сваё жыццё” (с.43). Ратавала і тое, што на фронце не было калі асабліва думаць, “жылі сёняшнім днём, - проста як расце трава”; не існававала “. ... цені сумнення, што ў нас, у арміі або кіраўніцтве, можа быць нешта неправільна” (с.44). “. . . У нас было перакананне, - працягвае аўтар успамінаў, - что без нас перамогі не будзе, таму пакуль ты здольны рухацца - патрэбна быць на пярэднім краі" (с.51). Побач з мужчынамі ваявалі жанчыны, але, па словах Льва Смілавіцкага, маладыя салдаты былі выхаваны цнатліва (с.52).

Аднак Леў Мацвеевіч не ідэалізуе франтавікоў. “Якіх толькі людзей не было сярод нас: былі і уркаганы, і проста ўзлаваныя, таму што фашысты забілі іх сем'і» (с. 70). У ходзе гвалтоўнай расправы раззлаваных салдат над ваеннапалоннымі шкадавання ў маладога Смілавіцкага не было, але існавала ніякаватасць, бо “...на тваіх вачах забівалі бязбройных людзей” (с.73.) На фронце Леў Мацвеевіч быў шафёрам, а таму сведчыць пра шматлікія аварыі ў пераможным 1945 годзе, калі п’яныя кіроўцы садзіліся за баранку і часам гінулі (с.88). Смілавіцкі заўважае, што савецкія салдаты адрозніваліся ад салдат вермахта. Яго вельмі здзівіла, што перад смерцю адзін з палонных немцаў пачаў ліхаманкава збіраць расспыпаныя па зямлі свае грошы. Аўтар тлумачыць: “Мы былі выхаваны ў пагардзе, у грэбаванні да грошай” (с.72). Так, яны ж, сапраўды, цанілі свае грошы і жыццё. 
Фронт - гэта пастаянная небяспека смерці. Ці можна было прывыкнуць да такой пастаяннай пагрозы? Былы салдат з Рэчыцы часта звяртаецца ва ўспамінах да гэтай тэмы. Сутыкаючыся на кожным кроку са смерцю, ён быў глыбока перакананы, што ўрэшце рэшт яго таксама заб'юць (с.81). Былі моманты, калі нават хацелася, каб забілі, каб прыпыніліся пакуты (с.68). І ў той жа час існавала вера ў шчаслівы лёс. Пры гвалтоўнай расправе раззлаваных салдат з ваеннапалоннымі, шкадавання ў маладога Смілавіцкага не было, але існавала ніякаватасць, “калі на тваіх вачах забівалі бязбройных людзей” (с.73.) Па сведчанню былога франтавіка, вайна ператварыла яго аднагодкаў у “маладых дзядуль” (с. 78). А “стан прыгнечанасці ад вайны і перажытага на ёй засталося ў мяне на ўсё жыццё”, - заключае ён (с.82).

Калі антысавецкія настроі савецкіх грамадзян добра апісаны, то пра псіхалогію салдата, шчырага савецкага патрыёта, звычайна, замоўчваюць або гавораць у форме палітычных лозунгаў, што выклікае недавер. А Льву Мацвеевічу верыш, бо ўсе яго выказванні адбывалася ў даверлівай размове 3 сынам. У пазнавальным плане яго ўспаміны аб псіхалогіі савецкага салдата-патрыёта ўяўляюць вялікую каштоўнасць. Былы франтавік шматкроць тлумачыць свае ўчынкі выхаваннем (“так нас выхоўвалі”). Мы, гісторыкі, відаць, сапраўды яшчэ недаацэньваем мілітарны дух сістэмы сталінскага выхавання, якая служыла магутным сродкам падрыхтоўкі моладзі да вайны.

Пасля вайны Леў Смілавіцкі паспяхова набывае вышэйшую кваліфікацыю ў юрыспрудэнцыі, паказвае сябе таленавітым лектарам, публіцыстам і арганізатарам. Гэтага часам было тады дастаткова, каб яўрэйскага юнака заўважылі ўлады і скарысталіся яго здольнасцямі.

Успаміны Льва Смілавіцкага пра пасляваенны перыяд жыця праліваюць святло на светапогляд прадстаўнікоў тагачаснай 
наменклатуры і эвалюцыю гэтага светапогляду. Узгадваючы пра смерць Сталіна, аўтар прызнае сябе сталіністам таго часу (c.121). А потым яму спатрэбіліся каласальныя інтэлектуальныя, духоўныя і маральныя высілкі, каб скарэкціраваць свае погляды і стаць зразумелым свайму сыну. Жыццё, як прызнаецца Леў Смілавіцкі, увесь час мяне папраўляла і ўносіла свае карэктывы (c.100).

Пасля вайны камсамольцы вазілі замежную моладзь у паказальныя калгасы. Леў Мацвеевіч сцвярджае, што тады яныбылі глыбока перакананымі ў маральнасці паказухі, бо ідэі сацыялізма лічыліся правільнымі і іх трэба было прапагандаваць. I далей дадае: “Крытыкі не разумеюць, што мы былі шчырымі. Ніхто ніколі наўмысна не падманваў. Мы былі людзьмі, добрасупленна трапіўшымі ў аблуду" (с. 110). Гэта, канешне, рызыкоўна ручацца за ўсіх. Але, відаць, сапраўды, успаміны Льва Смілавіцкага, у нейкай ступені адлюстроўваюць светапогляд і Пятра Машэрава. Аўтар ўспамінае, як жорстка важак беларускай камсамольскай моладзі ставіўся да камсамольцаў, якія пад акупацыяй згубілі або знішчылі свае камсамольскія білеты (с.111).

Былы камсамольскі прапагандыст быў, па яго прызнанню, актыўным абаронцам савецкай сістэмы да пераходу ў 1965 г. на працу ў Мінскі педагагічны інстытут імя Горкага (с.94). Сумненні пачалі перарастаць у крытычнае стаўлення да савецкіх ідэалаў 3 хрушчоўскай “адлігі”. Пасля выкрыцця Хрушчовым культа асобы Сталіна знікла і вера партыйнаму кіраўніцтву (с 114). А потым шмат чаго раскрыў красавіцкі (1985 г.) пленум ЦК КПСС. Пачалася “галоснасць”. Усё прыходзілася пераасэнсоўваць (с. 94). Праўда, не ўсе прадстаўнікі былой наменклатуры маглі і хацелі гэта рабіць. Дэкамунізацыя праходзіла з цяжкасцю. I ў 1980-я гады ў Льва Мацвеевіча, як і ў многіх прыхільнікаў перабудовы, захоўвалася вера ў Леніна. Ды і да сталіністаў ён працягваў адносіцца без варожасці, імкнуўся іх зразумець, лічыў, што 
такіх, якія ведалі сапраўднае становішча, але падпарадкоўваліся дзеля карьеры і выжывання, не было многа. Нават Сталін, на думку аўтара ўспамінаў, не быў прамым ворагам, але паверыў у свае метады і дайшоў да свавольства (с. 113). На думку былога франтавіка, заахвочванне ў час вайны самурайства апраўдвалася надзвычайнымі абставінамі (с. 113). Франтавік так і не адзначыў віну Сталіна ў масавай гібелі савецкіх салдат.

Наменклатурная мараль была для Льва Мацвеевіча дзіўнай, але вельмі высокай. І тут жа, відаць не выпадкова, у яго ўзнікае аналогія: “...У фашыстаў таксама была свая мараль”. Яна “не адпавядала агульначалавечым ідэалам, але яна была” (с.110). На гэтым кантрасце былы прадстаўнік наменклатуры хацеў, відаць, падкрэсліць, што мараль яго асяроддзя адпавядала агульначалавечым каштоўнасцям, але ў гэта верыцца 3 цяжкасцю.

Такой агульначалавечай маральнасцю, безумоўна, кіраваўся сам аўтар успамінаў. Жыццёвы вопыт Льва Смілавіцкага пацвярджае той факт, што сярод савецкай наменклатуры былі сумленныя, таленавітыя людзі, хоць, як правіла, не яны вызначалі палітычны курс краіны, а такія як Аляксандр Шэлепін. Выбіўшыся ў лідэра ўсесаюзнага камсамола, ён разгарнуў кампанію супраць так званых “стыляг”. А ў выступленні перад дэлегатамі ХХ з’езда камсамола Беларусі (1958 г.) маскоўскі госць заклікаў ужываць гвалтоўныя метады: псаваць моднае адзенне, абрэзаць доўгія валасы ў юнакоў, а то і збіваць іх фізічна. I ў пацярпелага потым ад камсамольцаў мінскага мастака, відаць, былі падставы назваць такія метады фашысцкімі (с.131).

Урэшце, са старонак кнігі вымалёўваецца неардынарная асоба Льва Мацвеевіча і яго лёс, у шмат чым тыповы для савецкіх патрыётаў, погляды якіх пакуль так мала вядомыя сучаснай моладзі і даследчыкам савецкага мінулага. Вера ў сацыялістычныя ідэалы, безумоўнае падпарадкаванне партыйнай дысцыпліне спалучаліся ў яго з прыроднай дабрынёй, сумленнасцю, мудрасцю, 
крытычным розумам. Гэта абумовіла добразычлівую, уважлівую і спакойную танальнасць успамінаў аўтара. Чытач не знойдзе там абвінавачванняў, зласлівых характарыстык. На першы погляд Леў Смілавіцкі, нібыта імкнецца апраўдаць сябе і партыйную наменклатуру, хоць, мяркуючы па яго чалавечых якасцях, ён проста тлумачыў сыну ўсю неадназначнасць абставін жыцця пры савецкай уладзе і непрадуктыўнасць навешвання на цэлае пакаленне ярлыкоў. Ён не ўтойваў непрыгожыя ўчынкі партыйцаў, падаваў іх з нейкім налётам шкадавання, але без жорсткага асуджэння. Леў Мацвеевіч, відаць, думаў, што іначай быць проста не магло, хоць тое, што было, яму не заўсёды падабалася.

Яго ўспаміны сведчаць аб існаванні сярод наменклатуры незадаволенасці. Тыя вырваўшыеся наволюдумкі,штовыкладзены ў размове з сынам, ўзніклі ж не толькі ў часы “галоснасці”. Яны былі рэакцыяй на канкрэтныя жыццёвыя сітуацыі мінулага, якія зберагла ўчэпістая памяць былога франтавіка.

Успаміны Льва Смілавіцкага маглі б і не пабачыць свет, каб не шчаслівае супадзенне. На завяршаючым этапе сваёй працоўнай дзейнасці ён набыў прафесію гісторыка. Акрамя таго, Льву Мацвеевічу пашчасціла мець сына, які, стаўшы гісторыкам, працягнуў справу бацькі. Па шчасліваму супадзенню (агульнае замілаванне гісторыяй), але ўсё ж не выпадкова запіс успамінаў мог адбыцца толькі ў канцы 1980-х гадоў, калі Леанід Львовіч ужо меў нейкі вопыт інтэрв'юіравання для ўласных навуковых патрэбаў, а Леў Мацвеевіч быў перакананы, што ва ўмовах “галоснасці” яго шчырыя ўспаміны не нашкодзяць сям'і. Можна было выказацца і тым вызваліць свядомасць ад цяжару мінулага. Наўрад ці думалі тады Смілавіцкія, сабраўшыся на летніку пад Мінскам для бяседы, што ствараюць важную гістарычную крыніцу для вывучэння вайны і паваеннага часу, і што ўспаміны некалі будуць надрукаваны. Тым больш, што гэта быў усяго толькі магнітафонны запіс. 
Мінула 30 гадоў. Доктар Леанід Львовіч Смілавіцкі стаў вядомым ізраільска-беларускім гісторыкам. I калі ён ушчыльную заняўся даследаваннем лістоў часоў Другой сусветнай вайны, калі сабраў, праглядаў і ўпарадкоўваў іх тысячамі, вывучыў шматлікія мемуары, дзённікі, успаміны, тады грамадская вартасць успамінаў бацькі стала яшчэ больш відавочнай. Пасля выдання пяці ўласных навуковых манаграфій, у Леаніда Львовіча ўзнікла магчымасць заняцца і падрыхтоўкай да друку ўспамінаў: перавесці іх у кампутарны і папяровы варыянт, вычытаць, зрабіць каментары, сабраць ілюстрацыі (дакументы, фотаздымкі, матэрыялы з сямейнага архіва), і выдаць уласным коштам у выглядзе бездакорнай у паліграфічным плане кніжкі.

Мяне здзівіла, як хутка мой калега па працы Леанід прайшоў шлях ад пераводу аўдыёзапісу на паперу да выдання. Акрамя характэрнай для яго аператыўнасці, мела значэнне i тая акалічнасць, што ўспаміны не патрабавалі літаратурнай апрацоўкі. Дарэчы, любы зацікаўлены чытач мае мажліваць заказаць аўдыёзапіс успамінаў у Леаніда Львовіча, што сведчыць пра адпаведнасць публікацыі аўдыёзапісу і яшчэ раз пацвярджае высокую каштоўнасць гэтай друкаванай крыніцы.

Кніга пачынаецца 3 пранікнёнай прадмовы сына. Далей Леанід Смілавіцкі вылучае ва ўспамінах 9 тэматычных частак. Успаміны ахопліваюць гістарычны перыяд ад нападзення нацыстаў Германіі на Савецкі Саюз (з некаторымі рэтраспекцыямі) да завяршэння працы Льва Смілавіцкага ў ЦК камсамола БССР (другая палова 1950-х). Аднак сын дае магчымасць чытачу азнаёміцца 3 далейшым лёсам бацькі, а для таго змяшчае ў кнізе ў якасці пасляслоўя біяграфічны артыкул прафесара Брэсцкага ўніверсітэта Міхаіла Стральца, раней апублікаванага ў беларускай прэсе ў сувязі з 90-годдзем Льва Мацвеевіча. I зусім лагічна, бо яго лёс быў даволі тыповым не толькі для савецкага патрыёта, але і для яўрэйскага інтэлігента БССР. На 
нейкім этапе сваёй працоўнай дзейнасці камсамольскі важак адчуў зверху шкляную столь. Яго паплечнікі займалі ўсё большы высокія пасады, а ён заставаўся ў нерухомасці. Таму прыйшлося перамяшчацца па гарызанталі: памочнік міністра культуры, стыльрэдактар выдавецтва “Беларусь”, дацэнт і выкладчык гісторыі КПСС Мінскага педінстытута, але не вышэй. Абараніць доктарскую дысертацыю не дазволілі. Калі чытаеш успаміны, пачынаеш разумець: камуністычныя ўлады маглі прыпыніць кар'ерны рост таленавітага чалавека, але не яго інтэлектуальны і духоўны рост. Быў, можа, адзіны шлях прабіцца наверх - гэта стаць прыстасаванцам, але Леў Мацвеевіч, зразумела, не мог ім скарыстацца. Пасля распада СССР і наступіўшай свабоды эміграцыі сям'я зрабіла у 1992 г. выбар на карысць пераезду ў Ізраіль. Леў Мацвеевіч падпарадкаваўся, можа таму, што не хацеў, каб яго сына і дачку напаткаў такі ж лес, як яго, бо добра ведаў, што такое савецкая ўлада, якая не магла знікнуць у адно імгненне.

Публікацыя ўспамінаў бацькі патрабавала ад сына пэўнай мужнасці. Адна справа мець кнігу для хатняга ўжытку, для захавання ўнукам успамінаў пра напоўненае выпрабаваннямі жыццё дзеда. Іншая справа зрабіць яе здабыткам грамадскасці. Постаць Льва Мацвеевіча Смілавіцкага зусім не простая, у шмат чым супярэчлівая і зусім не ўкладваецца ў рамкі героя або антыгероя. Чытачам савецкіх перакананняў разважанні аўтара ўспамінаў могуць падацца праявай апартунізму, а нацыяналістам сведчаннем нацыянальнай абыякавасці. Аднак Леанід Смілавіцкі, не зважаючы ні на што, робіць публікацыю. І робіць гэта дзеля навукі, каб даць гісторыкам яшчэ адно сведчанне сумленнага савецкага чалавека з наменклатуры пра жыццё пры савецкай уладзе. Яго статус у гэтым выданні нават цяжка вызначыць: хоць у загалоўку стаіць прозвішча бацькі, але фактычна ён выступае як аўтар кнігі, яе складальнік ці, можа лепей сказаць, сааўтар. I гэтай публікацыяй, дарэчы, Леанід Смілавіцкі працягвае тую 
справу, якую робіць Святлана Алексіевіч у вывучэнні, як яна кажа, “чырвонага чалавека".

Варта звярнуць увагу на тое, што выданне Смілавіцкіх стала вынікам паразумення прадстаўнікоў двух пакаленняў. Такое паразуменне, мяркуючы па гісторыі з дадзенымі ўспамінамі, наступае тады, калі старэйшае пакаленне шчыра дзеліцца сваімі думкамі, імкнецца патлумачыць свае ўчынкі і перажыванні, а ў прадстаўнікоў малодшага пакалення хапае розуму, каб зразумець сваіх бацькоу і пераняць у іх лепшае. Смілавіцкія пазбеглі канфлікта пакаленняў, характэрнага для пераломных эпох, i паказалі якраз прыклад іх пераемнасці. Сімвалічным сведчаннем таго можна разглядаць аб’ёмны дадатак да кнігі, дзе акрамя біяграфічнага нарыса, змешчаны копіі дакументаў бацькі і сына, у тым ліку каляровыя. Імкненне да пераемнасці і паразумення заўсёды прыносіць плён. Але гэты закон эвалюцыйнага развіцця грамадства часцей за ўсё парушаецца.

У заканчэнне застаецца дадаць, што кніга "Из опыта пережитого” мае некамерцыйны харктар і выстаўлена ў Інтэрнэце для ўсеагульнага доступа па спасылцы: https:/drive.google.com/file/d/0B7oINiwzNQRtbHVnLUpJcm11SEk/ view 